\title{
An Evaluative Study of English Language Teaching Methodology at Primary Level in
}

\section{Public Sector Schools of Hyderabad District}

\author{
* Nazir Bano, PhD Scholar \\ ** Prof. Dr. Parveen Munshi \\ *** Prof. Qalander Shah Lakiaree
}

\begin{abstract}
Teaching and learning of English have been given a prominent position in the education system of Pakistan. The study aimed to evaluate the teachers' methodology based on the activities in teaching English delimited to the government schools of Hyderabad district province Sindh. The stratified and random sampling techniques were applied to select the strata (boys \& girls schools) from the taluka Hyderabad city, taluka Latifabad, and taluka Qasimabad of the district Hyderabad. The data were collected through the closed-ended questionnaire from 120 primary school teachers and the English achievement test paper from 1078 students of grade five. The results showed that the relationship between the teaching methodology and the students' performance was significant. Therefore, an improvement in the teachers' teaching methods can enhance the students' performance in English. Likewise, the attitude of the teachers towards activities regarding learning English was negative. Moreover, the test result showed that only $11 \%$ of students passed the English test with the minimum test score while $89 \%$ of students failed the test. In the end, it was suggested that the government of Pakistan should arrange in-service training to train primary level school teachers. The teachers should focus more on activities and promote learning by doing techniques.
\end{abstract}

Keywords: English Teaching, Activities, Attitude of Teachers, Performance of Students. Introduction

English has a great appeal in the field of education. In Pakistan English has also a remarkable place. For example, with the growing scope of English, the government of Pakistan in the national education policy (2009) decided to teach English from the basic classes. The policy states, "The curriculum from Class I onward shall include English (as a subject)" (p.28). Therefore, now English has been taught in all public sector primary level like middle, elementary, lower secondary and mosque schools from class one. Hence, it is very important that young students take interest in learning a second language and it can be possible if they are taught by using a variety of effective student-centered teaching methods in the classroom. Indeed, a teacher plays an important part in teaching second languages and with the help of modern teaching methods and techniques students' performance can be increased successfully. Therefore, today teachers in the world prefer teaching English by applying activity-based methods. In the activity-based method, teachers remain facilitators and conduct some activities or games to make students alert and active. For example, a role-play activity is the most favorable technique in teaching a second language, as students participate and learn language skills easily. Similarly, there are scrabble or word puzzle activities that are also good to motivate students in learning new words of the second language.

However, old or traditional methods are not encouraged by educators and the researchers like Zahir (2014) points out that the grammar-translation method is an old method of the $19^{\text {th }}$ century of teaching a foreign or second language. Similarly, Awan and Shafi (2016) state that the grammartranslation method is not good to improve students' foreign language skills. Thus, nowadays researchers prefer teaching a second language by applying student-centered methods like activitybased methods. For instance, Anwer (2018) describes that through the activity-based method teachers easily gain students' confidence. The same, Albadi and David (2019) also favors activity-based teaching, according to them this is a good method because in this method students do not remain passive. Likewise, the study of Haq et al. (2017) proclaims that with the activity-based method

University of Sindh Email: banodero@yahoo.com

** Sufism University Bhitshah Email: munshiparveen@ gmail.com 
students' speaking and listening skills can be improved. Also, Khan et al. (2012) state that in the activity-based teaching method all students perform like active learners. There is another important fact about teaching through the activity-based method is the students' physical health, they are actively involved in thinking as well as in using their body parts. For example, games or activities can fit students from anxiety and many other problems they face at their home. Alike, Kohl and Cook (2013) consider that physical activity is a source of the fast motor skills of the students that are required to improve students' memory process. Likewise, Tomic (2008) describes that the habit of participation in the activities should be developed in students because through the activities students take an interest more in learning a second language. The same, many researchers investigated that activities have a positive effect on the students' performance, like Kayani et al. (2018) determined the positive correlation between the physical activities and the students' academic performance.

Besides, as in most of the primary government schools, we find a lack of playgrounds where students can play therefore, they stay mostly all the time in the classrooms and become lazy and boring. Thus, it is a good idea that students should be taught subjects like English in the classroom by activity-based techniques. As we know primary students' age is no more than 10 years so they enjoy more in playing games and the activities. Hence, through the activity-based method involving games, pair and share, and brainstorming techniques, students can take interest in learning and feel happy to learn a language that is not their mother tongue. In the same, academic behavior and achievement (good test score) can also be increased with the applications of the activities in the classroom. In short, primary school teachers should apply activities to make students physically and mentally healthy.

\section{Review of the literature}

Learning by doing is the term used for the activity-based method, indeed it is the student-cantered learning method in which no student remains passive, and primary school teachers should teach by play-based learning method (Eriyagama, 2018). Same, Anwer (2019) determined the positive effect of the activity-based method in improving students' achievement. She describes that it is the best method of teaching English because through this method students equally take part in the activity rather than sitting passively in the classroom as well as students gain creativity in the language skills. As, Thayniath (2015) states, "Activity-based learning plays a key role in developing the critical and creative mind of students" (p.33). Similarly, according to Hansraj (2017), a method is nothing but is a way of presenting a subject scientifically by keeping in mind the students' psychological and physical needs. Simply activity-based method is a method of keeping students in action. Moreover, activates not only engage students but they gain their self-confidence and their interest, increase day by day. Like in the play role method students enjoy and learn more and they apply practically at their homes with their other sisters and brothers.

Additionally, there are many benefits of the activity-based method from a health point of view, Rasberry et al. (2011) declare that if students are provided the opportunity for activity in the classroom then the students remain fit and perform better in academic achievement. It is mentioned in the Centers for disease control and prevention (2010) in the U.S department of health and human services that many factors affect the academic performance of the students, for example, the development of the students motor skills and the motor skills can help students to pay attention in the classroom and increase their verbal ability. In short, today researchers and educators prefer teaching a second or foreign language through activities to motivate students in learning English.

\section{Objectives}

1. To determine the relationship between the teachers' teaching methodology and students' performance in English at the primary school level.

2. To determine the attitude of the teachers towards teaching English based on activities.

3. To assess the performance of students in English.

\section{Statement of the problem}

The present study aimed to evaluate the primary public sector school teachers' teaching methodology in teaching English in Hyderabad district schools. Hassan et al (2015) criticize that in Pakistan English teaching is not praiseworthy. They add that to improve the students' language skills, training should be given to the English teachers to make them competent in teaching methods. Similarly, Ahmed, et al. (2013) describe that the majority of the government school teachers of Pakistan do not have the awareness of modern teaching techniques and they mostly use old traditional methods in the English class. Besides, Khan and Mansoor (2016) denounce that in Pakistan teachers teach English 
by the grammar-translation method. They further describe that in this method only translation and grammar rules are taught. Same, Hago-Eisa (2020) states that the grammar-translation method is the ineffective method in which teachers ignore the communication skills of the target language and it is the classical way of teaching foreign languages. However, Abali (2013) advises that an activity-based teaching method should be applied in teaching English to improve students' performance.

\section{Methodology}

The study was descriptive. The stratified sampling method was used to select the sample schools from Hyderabad city taluka, Latifabad taluka, and Qasimabad taluka of the Hyderabad district. The schools were randomly chosen from the approved lists of all the government primary level schools received from the concerned taluka education officers. Hence, the data was collected through the closed-ended questionnaire from 120 primary government schoolteachers (60 male \& 60 female) and English achievement test papers from 1078 five class students. The closed-ended questionnaire was designed to determine the teachers' methodology in teaching English at the primary level and teachers' responses were rated on a five-point Likert scale. Like, 1- Strongly agree 2- Agree 3- Undecided 4Disagree 5- Strongly disagree. The questionnaire had four sections regarding English language skills, like, oral communication skills, reading comprehension skills, writing skills, and grammar knowledge through the applications of the activities in the classroom. The researcher had chosen the material of the statements from the current textbook for class five students.

The same English test paper was developed for the students and all items were taken from My English book-5 that teachers taught them in the classroom. Shahbuddin (2015) is the author of My English book-5, she has given a detail of the teaching methodology in the introductory notes for the teacher; a teacher is emphasized to conduct an activity to teach language skills and knowledge of grammar. However, the validity of the questionnaire and the English test paper were tested by conducting pilot testing before starting the main research, whereas inter consistency or reliability of the questionnaire came 0.935 and 0.806 came for the English test paper, which was tested by using Cronbach alpha coefficient. Hence, after the confirmation of the validity and the reliability of the questionnaire and the test paper, data was collected from the participants and both descriptive and inferential statistics were used to analyze the data. The Pearson product-moment correlation coefficient was used to test the null hypothesis. The teachers' English teaching methodology was the independent variable while the students' performance was the dependent variable.

Table-5 Taluka wise size of the sample participants

\begin{tabular}{lllll}
\hline Taluka & Teachers & Percent & Students & Percent \\
\hline Hyderabad city & 58 & $48 \%$ & 463 & $43 \%$ \\
Latifabad & 44 & $37 \%$ & 412 & $38 \%$ \\
Qasimabad & 18 & $15 \%$ & 203 & $19 \%$ \\
Total & 120 & $100 \%$ & 1078 & $100 \%$ \\
\hline
\end{tabular}

Total size of the sample $=120+1078=1198$

\section{Findings}

Analysis of the closed-ended questionnaire

Table 6.1.1 Techniques to develop students 'English oral communication skills

\begin{tabular}{|c|c|c|c|c|c|c|}
\hline Section-1 & SA & A & UND & DA & SDA & Total \\
\hline Oral Communication skills & 1 & 2 & 3 & 4 & 5 & \\
\hline $\begin{array}{l}\text { To provide students an opportunity to } \\
\text { practice the oral dialogues and role play }\end{array}$ & 0 & 8 & 0 & 57 & 55 & 120 \\
\hline $\begin{array}{l}\text { To provide students a chance of the role- } \\
\text { playing dialogues in front of the } \\
\text { classmates }\end{array}$ & 0 & 15 & 0 & 55 & 50 & 120 \\
\hline $\begin{array}{l}\text { To help to play a game 'Guess who' to } \\
\text { gain students' confidence in speaking and } \\
\text { listening }\end{array}$ & 0 & 15 & 0 & 55 & 50 & 120 \\
\hline & $0 \%$ & (38) & & (167) & $(155)$ & $(360)$ \\
\hline Percent & & $11 \%$ & $0 \%$ & $46 \%$ & $43 \%$ & $100 \%$ \\
\hline
\end{tabular}




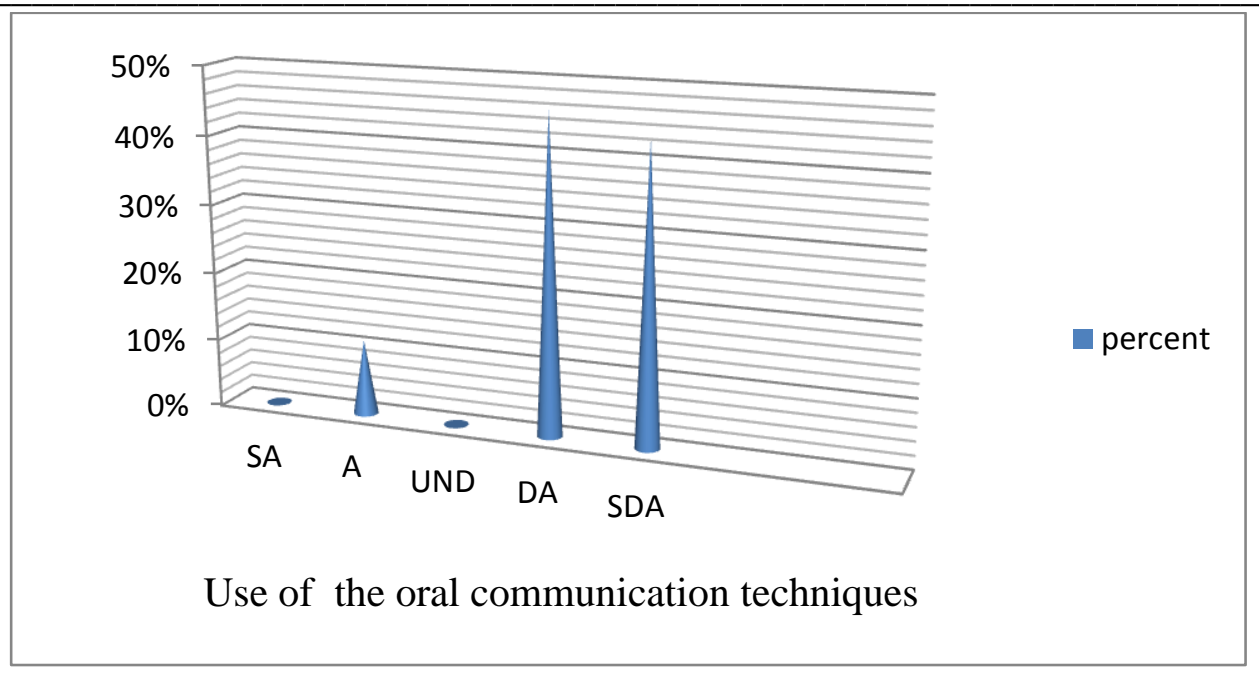

Figure 6.1.1 Activity-based techniques to teach oral communication skills

Table 6.1.2 Techniques to develop students 'reading comprehension skills

\begin{tabular}{|c|c|c|c|c|c|c|}
\hline Section-2 Reading skills & $\begin{array}{l}\text { SA } \\
1\end{array}$ & $\begin{array}{l}\text { A } \\
2\end{array}$ & $\begin{array}{l}\text { UND } \\
3\end{array}$ & $\begin{array}{l}\text { DA } \\
4\end{array}$ & $\begin{array}{l}\text { SDA } \\
5\end{array}$ & Total \\
\hline $\begin{array}{l}\text { Use of the pre-reading technique to } \\
\text { activate the prior knowledge of the topic }\end{array}$ & 0 & 65 & 0 & 0 & 55 & 120 \\
\hline $\begin{array}{l}\text { Use of the silent reading technique and } \\
\text { assign a task to students }\end{array}$ & 0 & 65 & 0 & 0 & 55 & 120 \\
\hline $\begin{array}{l}\text { Use of the post-reading technique, } \\
\text { involving reading comprehension } \\
\text { activities. }\end{array}$ & 0 & 15 & 0 & 55 & 50 & 120 \\
\hline Percent & $0 \%$ & $\begin{array}{l}(145) \\
40.3 \%\end{array}$ & $0 \%$ & $\begin{array}{l}(55) \\
15.3 \%\end{array}$ & $\begin{array}{l}(160) \\
44.4 \%\end{array}$ & $\begin{array}{l}(360) \\
100 \%\end{array}$ \\
\hline
\end{tabular}

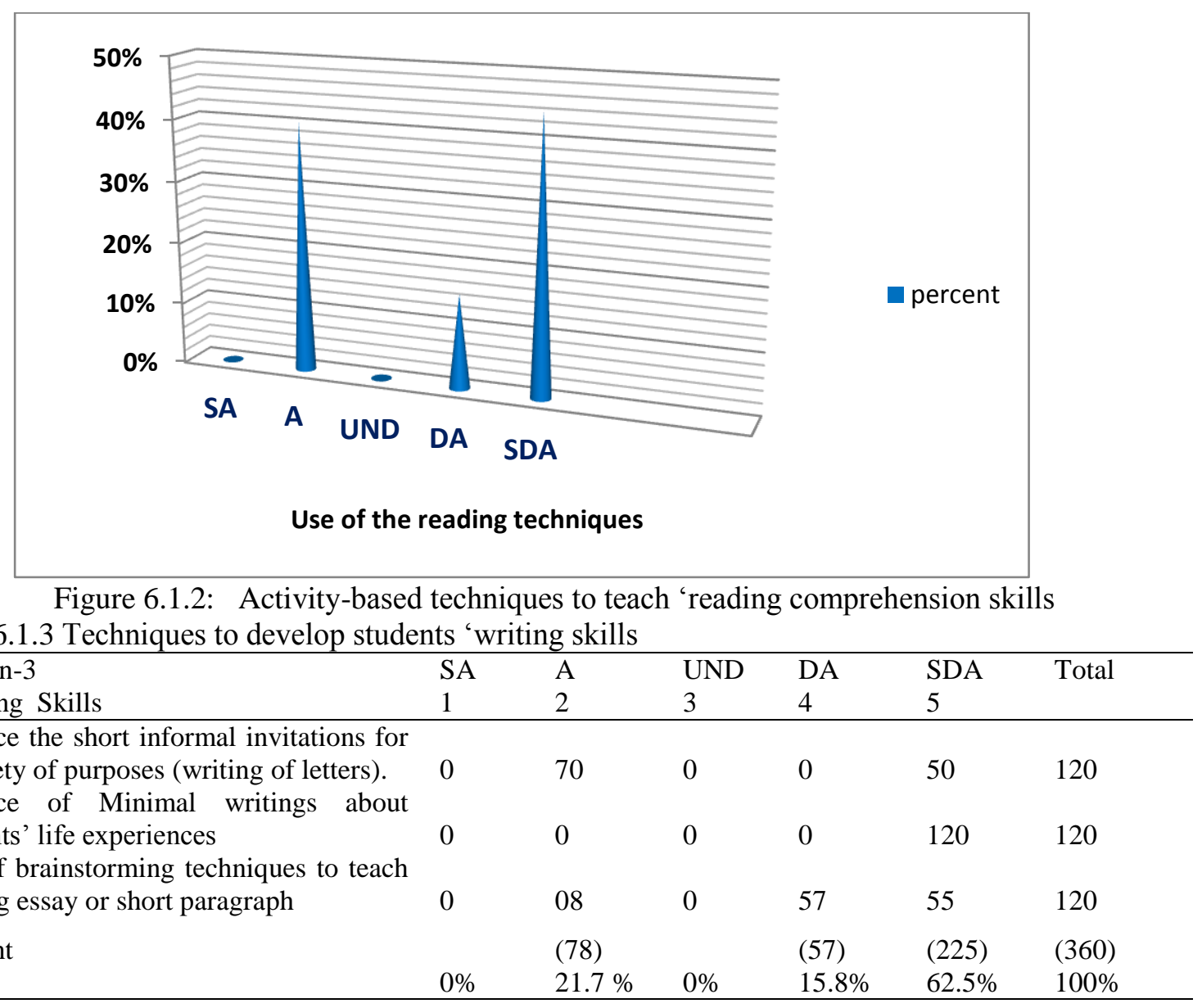




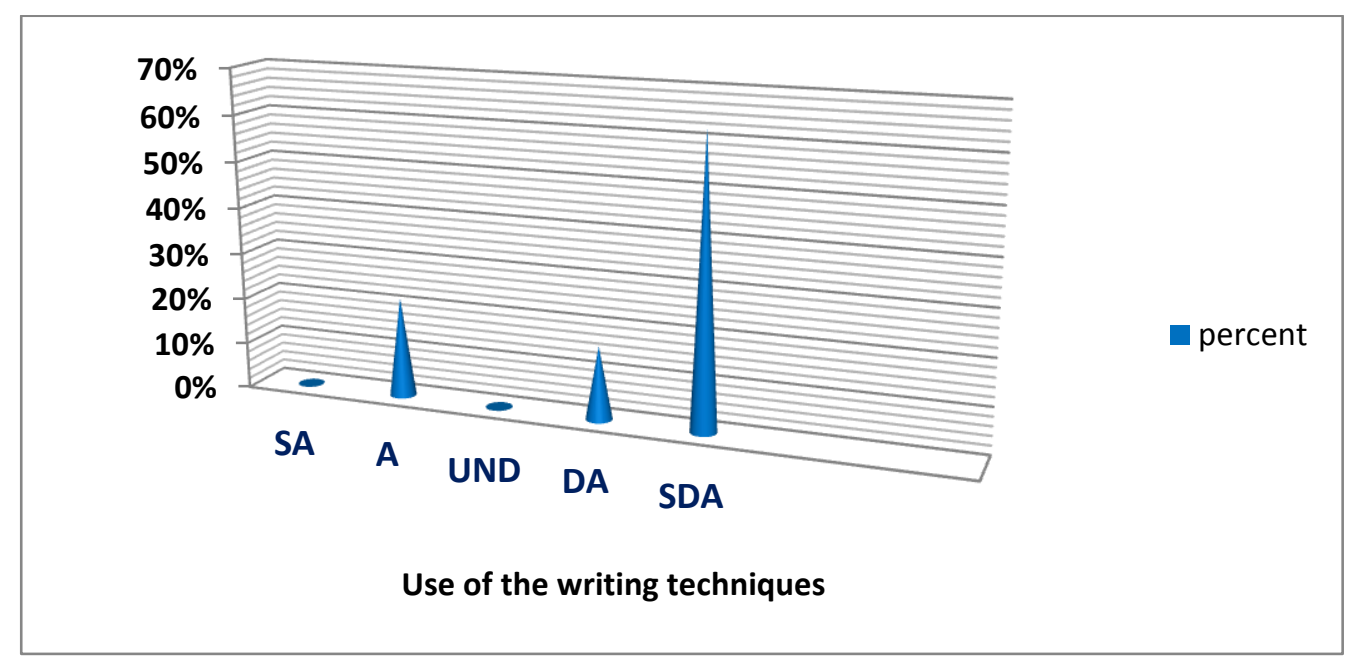

Figure 6.1.3: Activity-based techniques to teach writing skills

Table 6.1.4 Techniques to develop students 'grammar knowledge

\begin{tabular}{|c|c|c|c|c|c|c|}
\hline Section-4 Grammar & $\begin{array}{l}\text { SA } \\
1\end{array}$ & $\begin{array}{l}\text { A } \\
2\end{array}$ & $\begin{array}{l}\text { UND } \\
3\end{array}$ & $\begin{array}{l}\mathrm{DA} \\
4\end{array}$ & $\begin{array}{l}\text { SDA } \\
5\end{array}$ & $\begin{array}{l}\text { Tota } \\
1\end{array}$ \\
\hline $\begin{array}{l}\text { To teach the form and the usage of the } \\
\text { grammatical structures }\end{array}$ & 0 & 23 & 0 & 44 & 53 & 120 \\
\hline $\begin{array}{l}\text { To teach degrees of adjectives/ action } \\
\text { verb through a game }\end{array}$ & 0 & 65 & 0 & 0 & 55 & 120 \\
\hline $\begin{array}{l}\text { To make students use the learned } \\
\text { structures of tenses to express } \\
\text { themselves freely. }\end{array}$ & 10 & 05 & 0 & 0 & 105 & 120 \\
\hline Percent & (10) & (93) & $0 \%$ & (44) & $(213)$ & $(360)$ \\
\hline
\end{tabular}

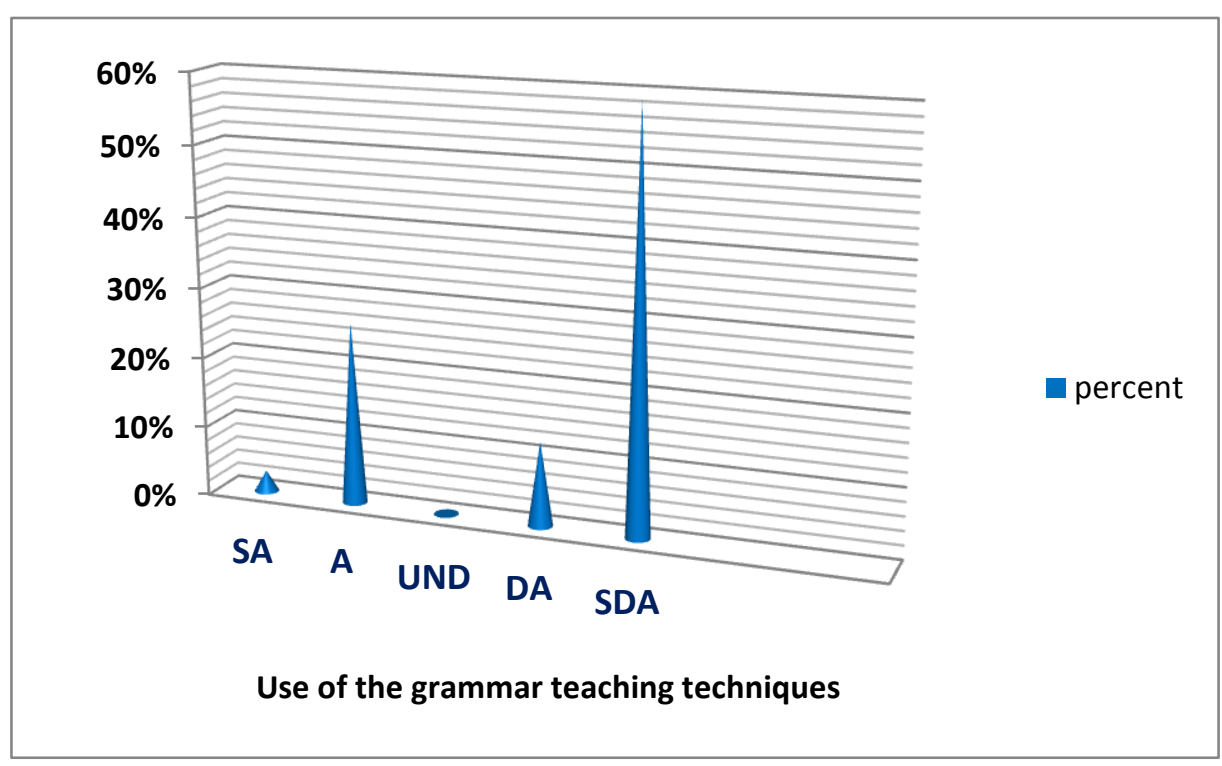

Figure 6.1.4: Activity-based techniques to teach grammar knowledge

Table 6.1.5: Teachers' attitude towards activity-based method

\begin{tabular}{|c|c|c|c|c|c|c|}
\hline Section 1-4 & $\begin{array}{l}\text { SA } \\
1\end{array}$ & $\begin{array}{l}\text { A } \\
2\end{array}$ & $\begin{array}{l}\text { UND } \\
3\end{array}$ & $\begin{array}{l}\mathrm{DA} \\
4\end{array}$ & $\begin{array}{l}\text { SDA } \\
5\end{array}$ & Total \\
\hline $\begin{array}{l}\text { Oral communication skills } \\
\text { (section-1) }\end{array}$ & $0 \%$ & $11 \%$ & $0 \%$ & $46 \%$ & $43 \%$ & $100 \%$ \\
\hline $\begin{array}{l}\text { Reading skills } \\
\text { (section-2) }\end{array}$ & $0 \%$ & $40.3 \%$ & $0 \%$ & $15.3 \%$ & $44.4 \%$ & $100 \%$ \\
\hline $\begin{array}{l}\text { Writing skills } \\
\text { (section-3) }\end{array}$ & $0 \%$ & $21.7 \%$ & $0 \%$ & $15.8 \%$ & $62.5 \%$ & $100 \%$ \\
\hline
\end{tabular}




\begin{tabular}{|c|c|c|c|c|c|c|}
\hline $\begin{array}{l}\text { Grammar knowledge } \\
\text { (section-4) } \\
\text { Total }\end{array}$ & $\begin{array}{l}03 \% \\
102 \%\end{array}$ & $26 \%$ & $\begin{array}{l}0 \% \\
\text { UND }\end{array}$ & $\begin{array}{l}12 \% \\
298 \%\end{array}$ & $59 \%$ & $\begin{array}{l}100 \% \\
400\end{array}$ \\
\hline Percent in all four sections & $\begin{array}{r}102 \\
25.5 \% \\
\text { Agree }\end{array}$ & $\times 100=$ & & $\begin{array}{r}289 / \\
74.5 \% \\
\text { Disagr }\end{array}$ & $100=$ & \\
\hline
\end{tabular}

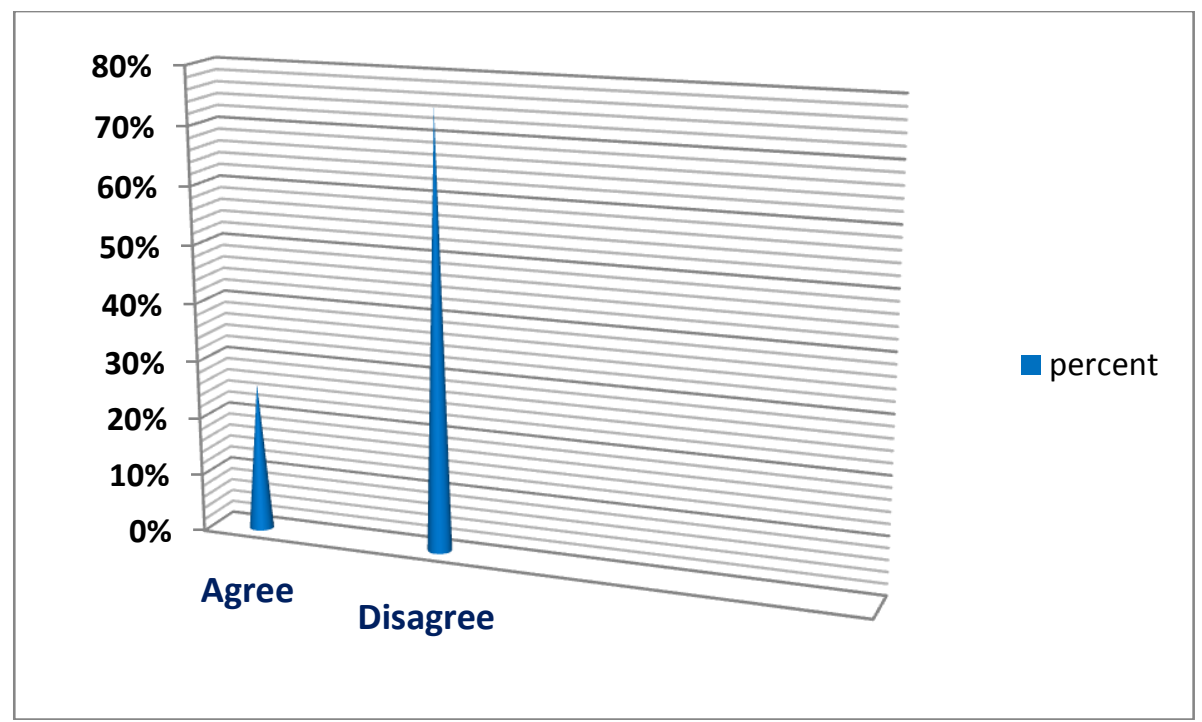

Figure 6.1.5: Activity-based techniques to teach English

\section{Summary of the closed-ended questionnaire results}

Table 6.1 .1 summarizes that only $11 \%$ of teachers agreed to apply the activity-based techniques in the classroom to develop students' English oral communication skills. However, $46 \%$ of teachers disagreed and $43 \%$ of teachers strongly disagreed that they did not apply the activity-based techniques in the English classroom. Similarly in the reading comprehension section, table 6.1.2 describes that only $40.27 \%$ of teachers agreed to apply the activities to develop and enhance the students' reading skills while $15.27 \%$ of teachers disagreed and $44.44 \%$ of teachers strongly disagreed to apply such techniques in the classroom. Thus, from the analysis, it was concluded that $60 \%$ of teachers avoided teaching reading skills with the activity-based method.

Moreover, in the writing section, table 6.1.3, explains that only $21.7 \%$ of teachers agreed to apply activity-based techniques to develop and improve students' English writing skills, while $62.5 \%$ of teachers strongly disagreed and $15.8 \%$ of teachers disagreed to apply such techniques in the classroom. Hence, on the whole, $78 \%$ of teachers denied applying activity-based techniques to improve students' creativity in English writing. Also, in the grammar section, table 6.1.4, describes that only $03 \%$ of teachers strongly agreed and $26 \%$ of teachers agreed to improve students' basic knowledge of grammar by applying activities. However, $59 \%$ of teachers strongly disagreed and $12 \%$ of teachers disagreed to apply such a method. Thus, $71 \%$ of teachers denied teaching grammar knowledge with activity-based techniques. Table 6.1.5 summarizes the result of all four sections including oral communication, reading, writing, and grammar knowledge. The table describes that only $25.5 \%$ of teachers applied activities to teach English while $74.5 \%$ of teachers disagreed to apply the activities in the classrooms. Therefore, it was concluded that the majority of the teachers taught English by applying old methods.

\section{Analysis of the students' performance in English achievement test paper}

Table: 6.2: Performance of the students' in English test paper

\begin{tabular}{lccccc}
\hline Taluka & Students & Pass & Percent & Fail & Percent \\
\hline Hyderabad City & 462 & 60 & $13 \%$ & 402 & $87 \%$ \\
Latifabad & 413 & 35 & $08 \%$ & 378 & $92 \%$ \\
Qasimabad & 203 & 25 & $12 \%$ & 178 & $88 \%$ \\
Total & 1078 & 120 & & 958 & \\
Percent & & $11 \%$ pass & & $89 \%$ Fail & \\
\hline
\end{tabular}

Students passed $11 \%$ and failed $89 \%$ 


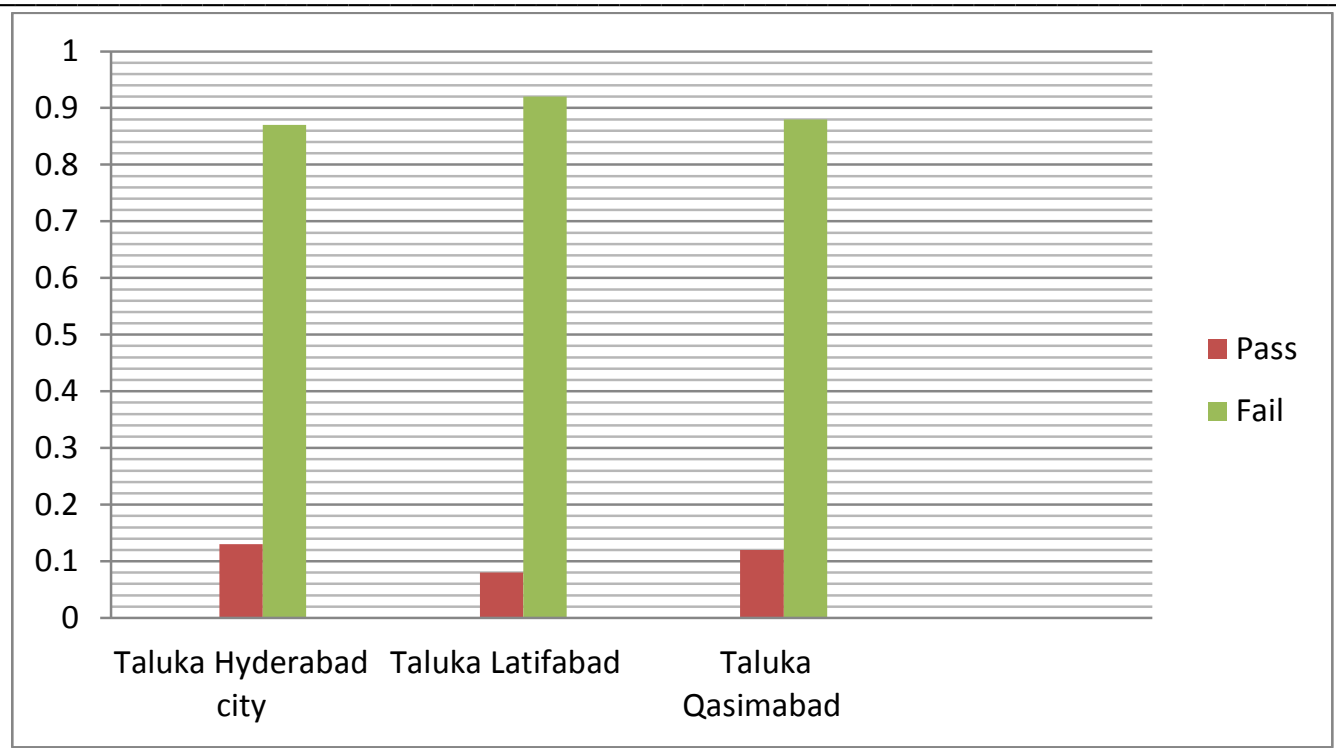

Figure 6.2, Performance of the students in English test paper

To determine the relationship between the teachers' teaching methodology and the students' performance.

Hypothesis- There is no significant relationship between the teachers' teaching methodology and their students' performance.

Table 6.3: Pearson correlation -testing

\begin{tabular}{llll}
\hline & & Teaching methodology & Students' performance \\
\hline Teaching & Pearson correlation & 1 & $.218^{*}$ \\
methodology & Sig. (2-tailed) & & .016 \\
& $\mathrm{~N}$ & 120 & 120 \\
Students' & Pearson correlation & $.218^{*}$ & 1 \\
performance & Sig. (2-tailed) & .016 & 120 \\
& $\mathrm{~N}$ & 120 & \\
\hline
\end{tabular}

*.Correlation is significant at the 0.05 level (2-tailed)

Table 6.3 explains that the correlation was significant at the 0.05 level as the p-value (.016) was less than the significant alpha level $(\mathrm{p}<.05)$. Hence, the null hypothesis was rejected and it was determined that there was a significant positive relationship between the teachers' teaching methodology and their five grade students' performance in the English achievement test paper.

\section{Discussion}

\section{Effect of teaching methodology on students" performance}

From the correlation test, it was determined that the teachers' teaching methodology and the students' performance were positively correlated with each other, which means teachers' efficiency in the teaching methods will affect the students' performance. However, the results from the closed-ended questionnaire exposed that only $25.5 \%$ of teachers accepted that they applied activities to develop students' English language skills and knowledge of grammar but $74.5 \%$ of teachers disagreed to teach English by using such techniques. Therefore, it was determined that the primary level schoolteachers taught the English language by applying old methods and techniques in the classroom. Besides, students' performance in English achievement test paper was shocking, only $11 \%$ of students obtained minimum test scores while $89 \%$ of students did not pass the test. Hence, there is a need to change the attitude of the English primary school teachers about teaching English because with the old grammartranslation method students only become perfect in translating the text but they do not gain creativity in the writing and oral communication skills. Similarly, by teaching the old or grammar-translation method, students can only memorize the text but cannot write a single sentence by themselves. Today English stands as a global language and has a great scope in the education system. For example, English is used as the medium of instruction for teaching science and technology. Therefore, the public primary sector schoolteachers of Pakistan need to teach English by applying activity-based methods to make their students' performance better in English. Hence, teachers should realize the effect of activity-based teaching in learning a second language and avoid teaching by applying the traditional method. As Nawab (2012) states that mostly in Pakistan teachers teach English as a 
subject. Teachers know teaching methodologies are different for teaching a second or foreign language. Alike, the study of Haq et al. (2015) revealed the better performance of the students in learning listening skills who were taught through activity-based teaching method. Similarly, Anwer (2019) states that the activity-based teaching method is the best method that helps to develop students' interest in learning second languages. Therefore, there is a need of changing primary school teachers' attitudes towards teaching through effective modern teaching methods to develop students' creativity in English language skills.

\section{Conclusion}

An improvement in teaching methods would enhance the performance of students in English because there was a significant relationship between the teaching methods and the students' performance. The attitude of teachers towards teaching English based on activities was not positive, consequently, the performance of students in English was unsatisfactory.

\section{Suggestions}

The suggestions are based on the findings of the study. The positive relationship was determined between the teachers' teaching methodology and their students' performance. Therefore, the teachers should adopt the latest activity-based method in the classroom to enhance the students' performance. The government should take serious steps to ensure the provision of quality education in the government sector primary schools. Moreover, the government should appoint professionally qualified English teachers who know the modern teaching methods and techniques to uplift the standard of teaching-learning of English. Similarly, the government should also provide enough funds for the English quality based on service primary school teachers' pieces of training because the majority of the primary teachers do not know the student's centered methods. There is a need to change the attitudes of the primary teachers about teaching English by using activity-based techniques in the classroom.

\section{References}

Abali, N. (2013). English language teachers' use of competence in and professional development needs for specific classroom activities. Procedia-Social and Behavioral Sciences, 70(1), 181 - 187. https://doi.org/10.1016/j.sbspro.2013.01.054

Ahmed, N., Khan, F. N., \& Munir, N. (2013). Factors affecting the learning of English at secondary school level in Khyber Pakhtunkhwa, Pakistan. International Journal of English language and literature studies. 2(2), 95-101. http://www.ideas.repec.org > ASI > ijells > 2013p95-101

Albadi, A., \& David, S.A. (2019). The impact of activity-based learning on students' motivation and academic achievement: A study among 12th-grade science and environment students in a public school in Oman. Specialty Journal of Knowledge Management, 4(4), 44-53. https://www.researchgate.net/publication/339503612_The_Impact_of_Ac

Anwer, F. (2019). Activity-based teaching, student motivation, and academic achievement. Journal of Education and Educational Development, 6(1), 154-170. https://files.eric.ed.gov > full text

Awan, G.A., \& Shafi, M. (2016). Analysis of teaching methods of English language at government secondary school level in D.G. Khan city-Pakistan. An International Peer-reviewed Journal, 26(1), 9-17.https://www.iste.org > Journals > index.php > JLLL > article > download

Centers for Disease Control and Prevention. (2010). the association between school-based physical activity, including physical education, and academic performance. U.S Department of Health and Human Services. (pp.84) https://www.cdc.gov/healthyyouth/health_and_academics/ pdf/pa-pe_paper.pdf

Eriyagama, S. (2018). Activity-based teaching methods for better learning in primary mathematics classrooms. World Voices Nexus 2(2) https://www.worldcces.orgyarticle-3-by-eriyagama > use-of activity-based-t...

Hago-Eisa, S.A. (2020). "The pros and cons of the grammar-translation method on the performance of Saudi EFL learners". Arab Journal for Scientific Publishing, 1(1), 381-392. https://www.ajsp.net > research > The Pros and Cons https://www.ajsp.net > research > The Pros and Cons

Haq, Z. U., Khan, A., \& Tabassum, R. (2015). Effect of ABL method on students' performance in listening skill at grade-VI, Journal of humanities and social sciences, XXIII (.3), 95-108. https://www.researchgate.net > publication > 317795437_Effect_. 
Haq, Z. U., Khurram, B.A., \& Bangash, A.K. (2017). Development of speaking skills through activity-based learning at the elementary level. Eurasian Journal of Educational Research, 69(1), 241-252. https://files.eric.ed.gov/fulltext/EJ1148809.pdf

Hansraj. (2017). Activity-based teaching-learning strategy in language. International Journal of English language literature, Humanities, 4(20), 4433- 4436.

Kayani, S., Kiyani, T., Wang, J., Sánchez, M.Z., Kayani, S., \& Qurban, H. (2018). Physical activity and academic performance: the mediating effect of self-esteem and depression. https://www.mdpi.com > pdf

Khan, A.B., \& Mansoor, H. S. (2016). The effectiveness of the grammar-translation method in teaching and learning of English language at the intermediate level. International Journal of Institutional \& Industrial Research, 1(1), 22-25.

http://www.academia.edu > The_Effectiveness_of_Grammar_Translation_Met...

Khan, M., Muhammad, N., Ahmed, M., Saeed, F., Khan, S.A. (2012). Impact of activity-based teaching on students' academic achievements in physics at the secondary level. Academic Research International, 3(1), 146-156. https://www.savap.org.pk > journals > ARInt. > Vol.3(1) > 2012(3.1-19).pdf

Kohl, H.W. III., \& Cook, H.D. (2013). Educating the student body: Taking physical activity and physical education to school. National Academies Press (US) https://www.ncbi.nlm.nih.gov > books > NBK201501

National Education Policy. (2009). Ministry of education Islamabad government of Pakistan.https://www.itacec.org/document/2015/7/National_Education_Policy_2009.pdf

Nawab, A. (2012). Is it a way to teach language the way we teach a language? English language teaching in rural Pakistan: Academic Research International Journal, 2(2), 696-705. http://www.savap.org.pk > journals > ARInt. > Vol.2 (2) > 2012(2.2-76).

Raspberry, C.N., Lee, S.M., Robin, L., Laris, B.A., Russell, L.A., Coyle, K.K, \& Nihiser, A.J. (2011).The association between school-based physical activities, including physical education, and academic performance: A systematic review of the literature. Journal of Preventive Medicine, 52(1), 510-520. https://www.bjcschooloutreach.org/Portals/0/Tools\% 20 for $\% 20$ Building $\%$

Shahbuddin, F. (2015). My English Book-5 ( ${ }^{\text {st }}$ Ed.) Sindh textbook board Jamshoro, Sindh government Pakistan.

Thayniath, S. (2015). Activity-based language learning in the classroom: An effective learning method. International Journal of English language literature, Humanities, 3(5), 33- 40, http://ijellh.com/OJS/in dex.php/OJS/article/view/539/539

Tomic, R. (2008). Adolescent attitudes towards sport depending on school level, gender, and school sports club membership. Journal of Human Kinetics volume 20(1), 121-130. http://www.johk.pl > files > 11_tomik

Zahir, F. (2014). Teaching methods of foreign languages teaching and learning of the Spanish language in Kabul. (Unpublished thesis for the degree of Bachelor), Kabul University Karlstad, Sweden). (pp.41). http://www.pdfs.semanticscholar.org > 